\title{
Microfacies, foraminifers and carbon and oxygen isotopes in a basinal section of the Zechstein Limestone (Wuchiapingian): Bonikowo 2 borehole, western Poland
}

\author{
Danuta PERYT ${ }^{1}$, Tadeusz Marek PERYT ${ }^{2,}$ *, Stanisław HAŁAS ${ }^{3}$ and Paweł RACZYŃSKI ${ }^{4}$ \\ 1 Polish Academy of Sciences, Institute of Paleobiology, Twarda 51/55, 00-818 Warszawa, Poland \\ 2 Polish Geological Institute - National Research Institute, Rakowiecka 4, 00-975 Warszawa, Poland \\ 3 Maria Curie-Skłodowska University, Institute of Physics, Mass Spectrometry Laboratory, 20-031 Lublin, Poland \\ 4 University of Wrocław, Institute of Geological Sciences, PI. Maksa Borna 9, 50-205 Wrocław, Poland
}

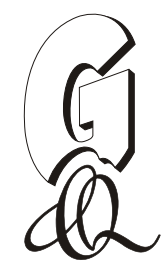

Peryt, D., Peryt, T.M., Hałas, S., Raczyński, P., 2016. Microfacies, foraminifers and carbon and oxygen isotopes in a basinal section of the Zechstein Limestone (Wuchiapingian): Bonikowo 2 borehole, western Poland. Geological Quarterly, 60 (4): 827-839, doi: 10.7306/gq.1326

\begin{abstract}
The Zechstein Limestone of the Bonikowo 2 borehole is composed of limestone with varied dolomite content and is slightly thicker $(3.4 \mathrm{~m})$ than other supposed condensed sections in SW Poland. The microfacies (mostly bioclastic wackestones-packstones) are characteristic of open marine limestone deposited in deep shelf environments. The common occurrence of echinoids in all parts of the section, except close to its top, indicates no essential change in sea water salinity. However, the palaeotemperature interpretation of the highest $\delta^{18} \mathrm{O}$ value of calcite recorded in the Bonikowo 2 borehole $\left(+0.32 \%\right.$ ) indicates a temperature of $22.9^{\circ} \mathrm{C}$ when a $\delta^{18} \mathrm{O}$ of water $=2 \%$ is assumed. The $\delta^{13} \mathrm{C}$ and $\delta^{18} \mathrm{O}$ curves for calcite and dolomite are similar in shape, and their mean values are similar: $+1.8 \pm 1.5 \%$ for calcite, respectively, and $+1.9 \pm 2.3 \%$ and $-4.3 \pm 2.4 \%,-3.8 \pm 4.3 \%$ for dolomite. There is a recrystallized interval in the lower part of the section with both $\delta^{13} \mathrm{C}$ and $\delta^{18} \mathrm{O}$ values reduced. This may be regarded as an aerobic equivalent of the Kupferschiefer. The diversity and abundance of foraminifers is significant throughout the section studied; lagenids prevail, and this is considered to be due to the dysaerobic conditions throughout the duration of deposition of the Zechstein Limestone.
\end{abstract}

Key words: Foraminifers, carbon and oxygen isotopes, Wuchiapingian, basin facies, Zechstein Limestone, Poland.

\section{INTRODUCTION}

Late Permian reefs in the central part of the Zechstein Limestone basin in Poland grew on the topmost edges of tilted blocks and/or on the top of uplifted horsts of the Brandenburg-Wolsztyn-Pogorzela palaeo-High (Dyjaczynski et al., 2001; Kiersnowski et al., 2010; Peryt et al., 2012b). On one such block the Bonikowo Reef was established. The thickness of the Zechstein Limestone in the Bonikowo 1 borehole, that is located in the reef centre, is $87.5 \mathrm{~m}$. In the Bonikowo 2 borehole that is adjacent to the Bonikowo Reef, the Zechstein Limestone is $3.4 \mathrm{~m}$ thick and occurs at a depth of $2448.4-2451.8 \mathrm{~m}$. It is underlain by the Weissliegend and then Rotliegend sandstones and conglomerates. The earlier petrological (Sylwestrzak, 2001) and petrophysical (Ziemianin, 2012) studies indicated that the dark micritic limestones with minor dolomite are homogeneous and show porosity mostly $<1 \%$ and permeability

\footnotetext{
* Corresponding author, e-mail: tadeusz.peryt@pgi.gov.pl
}

Received: August 31, 2016; accepted: October 21, 2016; first published online: November 4, 2016
$<0.01 \mathrm{mD}$, with fauna recorded in the upper part of the interval that is represented by bryozoans, ostracods, foraminifers and shells of bivalves or brachiopods (Ziemianin, 2012). Such a faunal assemblage is similar to that typical of the carbonate platform (e.g., Hara et al., 2013).

In general terms, such development is characteristic of the specific facies termed "condensed" (Peryt and Ważny, 1980; Peryt et al., 2015). As a rule, the condensed sequences are $<2.5 \mathrm{~m}$ thick, often <1 m thick (Peryt and Ważny, 1980; Dyjaczyński and Peryt, 2014; Peryt et al., 2015) in contrast to typical basinal Zechstein Limestone sequences which are 5-10 m thick (Peryt et al., 1978; cf. Kotarba et al., 2006). The Zechstein Limestone of the Bonikowo 2 borehole is thicker than most such condensed sequences and one possible explanation of this slight thickness increase is the contribution of material derived from the Bonikowo Reef; thus one of the aims of this paper is to consider the impact of the reef on deposition in the adjacent area. Earlier study of typical condensed sequences (Peryt et al., 2015) suggested continual dysaerobic conditions, and possibly elevated salinity of sea water, during deposition of thin basinal Zechstein Limestone deposits. The aim of this paper is to establish the environmental conditions in close proximity to the basinward side of the Bonikowo Reef. In contrast to the thick reef sequences which lack the characteristic $\delta^{13} \mathrm{C}$ curve of the lowermost part of the Zechstein, the thin 
condensed sequences probably record the entire interval of the Zechstein prior to the onset of evaporite deposition (Peryt et al., 2015); hence the Bonikowo 2 section offers an additional possibility to test the validity of isotopic correlation of reef and basinal profiles.

\section{GEOLOGICAL SETTING}

The Bonikowo 2 borehole is located NE of the Bonikowo 1 borehole (Fig. 1). The Zechstein deposits of the Bonikowo 2 borehole are underlain by an $187 \mathrm{~m}$ thick sequence of Rotliegend (including Weissliegend) conglomerates and sandstones deposited in the Poznań Basin (Dyjaczyński and Kucharczyk, 2000). The Bonikowo Reef is covered by the PZ1 anhydrites, $37.0 \mathrm{~m}$ thick; the total Zechstein thickness is $414.5 \mathrm{~m}$ (Kiersnowski et al., 2010: table 1). In the Bonikowo 2 borehole, the thickness of the PZ1 anhydrites is $93.1 \mathrm{~m}$ (Peryt et al., 2010b: fig. 4), and the total Zechstein thickness is $405.5 \mathrm{~m}$ (Kiersnowski et al., 2010: table 2). Assuming a roughly planar surface of the Zechstein top in both boreholes and the distinct elevation of the Bonikowo Reef block compared to the Bonikowo 2 borehole at the onset of the Zechstein Limestone deposition, the subsidence of the Reef block had to exceed that of the block on which the Bonikowo 2 borehole is located.
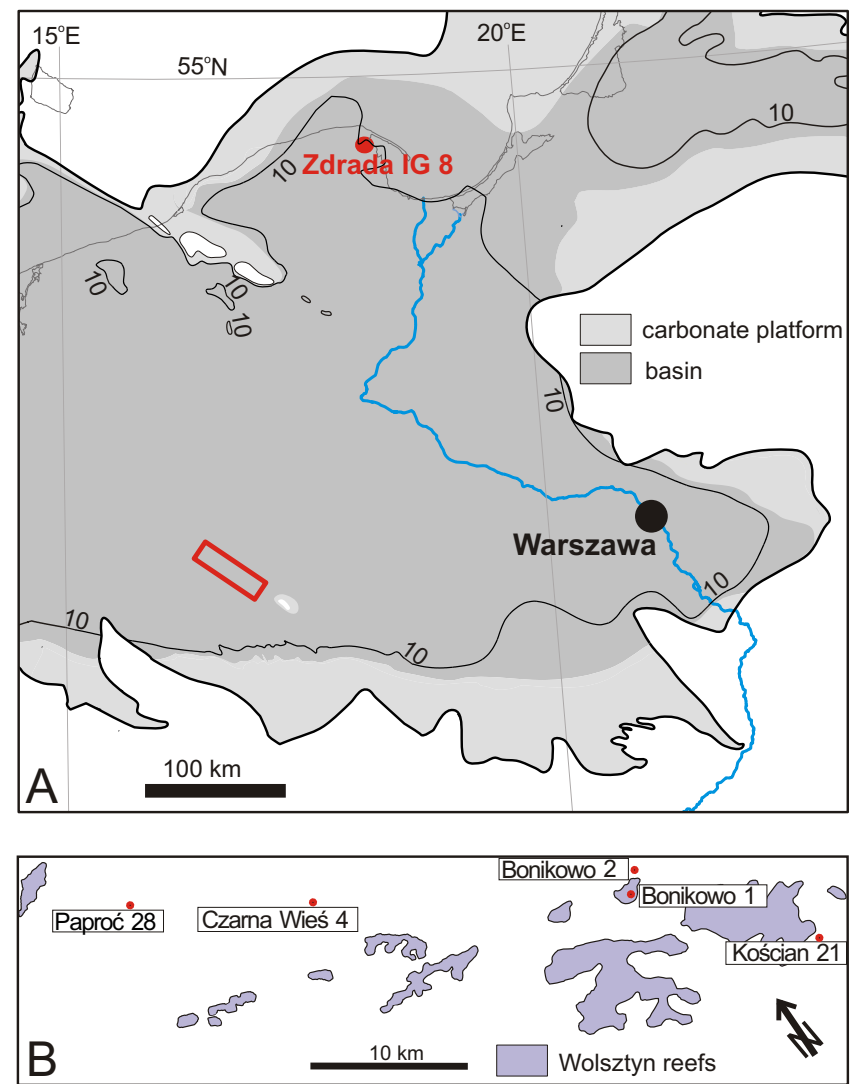

Fig. 1A - the location of the Bonikowo 2 borehole on a map showing the general palaeogeographical zones of the Zechstein Limestone (the isopach $10 \mathrm{~m}$ in the basin zone after Peryt et al., 2010a); the quadrangle shows the area of Figure 1B; B the distribution of the Wolsztyn reefs (from $>10$ to $90.5 \mathrm{~m}$ thick) and the locations of the boreholes referred to in the text
The Zechstein Limestone is overlain by Lower Anhydrite (73 $\mathrm{m}$ thick), composed of bedded anhydrite with pseudomorphs after upright-growth gypsum crystals, then clastic anhydrite and thick massive anhydrite with pseudomorphs after upright-growth gypsum crystals forming the major part of the Lower Anhydrite. This massive anhydrite contains, in its upper part, an intercalation of bedded anhydrite with pseudomorphs after upright-growth gypsum crystals. The upper part of the Lower Anhydrite is composed of clastic and then bedded anhydrite (Denison and Peryt, 2009). These deposits originated in shallow salina environments (cf. Peryt, 1994).

\section{METHODS}

Macroscopic observations on borehole were complemented by study of 25 thin-sections (including 7 thin-sections belonging to the Polish Oil and Gas Company which were previously studied by Sylwestrzak, 2000).

The Zechstein Limestone section was sampled for carbon and oxygen isotopic studies; altogether 13 samples were analysed. A $1.5 \mathrm{~mm}$ diameter stainless steel drill was used for the extraction of material from the surfaces of the samples although the diameter of holes drilled was about $4 \mathrm{~mm}$. Isotopic analysis was carried out at the UMCS Lublin Mass Spectrometry Laboratory using a dual inlet and triple collector mass spectrometer (a modified and modernized Ml1305 model). In this analysis we have applied selective acid extraction (Al-Aasm et al., 1990). Calcite fractions of carbonates were analysed on $\mathrm{CO}_{2}$ produced by reaction with $100 \% \mathrm{H}_{3} \mathrm{PO}_{4}$ in a glass vacuum line connected to the inlet system of the mass spectrometer. The reaction proceeded at an electronically controlled temperature of $25 \pm 0.2^{\circ} \mathrm{C}$ to achieve $\delta^{18} \mathrm{O}$ in the PDB scale. For normalization of both $\delta^{13} \mathrm{C}$ and $\delta^{18} \mathrm{O}$ values the international standard NBS-19 was analysed in each series of samples. After isotope analysis of the calcite fraction the temperature was switched to $50 \pm 0.2^{\circ} \mathrm{C}$ for analysis of the dolomite fraction. $\mathrm{CO}_{2}$ evolved during temperature increase from 25 to $50^{\circ}$ was evacuated. Thereafter, the reaction tubes were isolated from vacuum and remained closed for 24 hours. After this time, $\mathrm{CO}_{2}$ gas of the dolomite fraction was analysed similarly to that of the calcite fraction. The analytical uncertainty of both $\delta$ values in terms of standard deviation was better than $0.08 \%$ for the calcite fraction and about $0.15 \%$ for the dolomite fraction. For the last fraction $\delta^{18} \mathrm{O}$ was corrected for acid fractionation according to Rosenbaum and Sheppard (1986).

\section{RESULTS}

Lithology. As previously noted by Sylwestrzak (2001) and Ziemianin (2012), the Zechstein Limestone mostly comprises limestone with varied dolomite contents and small amounts of insoluble residue, mainly quartz (3-7\% according to Sylwestrzak, 2001; decreasing upwards). Late diagenetic anhydrite cements are rare and occur as mould fillings and tabular crystals impregnating the matrix. On the other hand, syndepositional anhydrite nodules are moderately common (Fig. 2); their textures differ from that of the anhydrite cement by very fine, elongated crystals that are chaotically arranged (Sylwestrzak, 2001).

Where present, dolomite occurs mostly in the matrix. Sylwestrzak (2001) noted a notable exception is the lowermost part of the section that is composed of recrystallized carbonate 


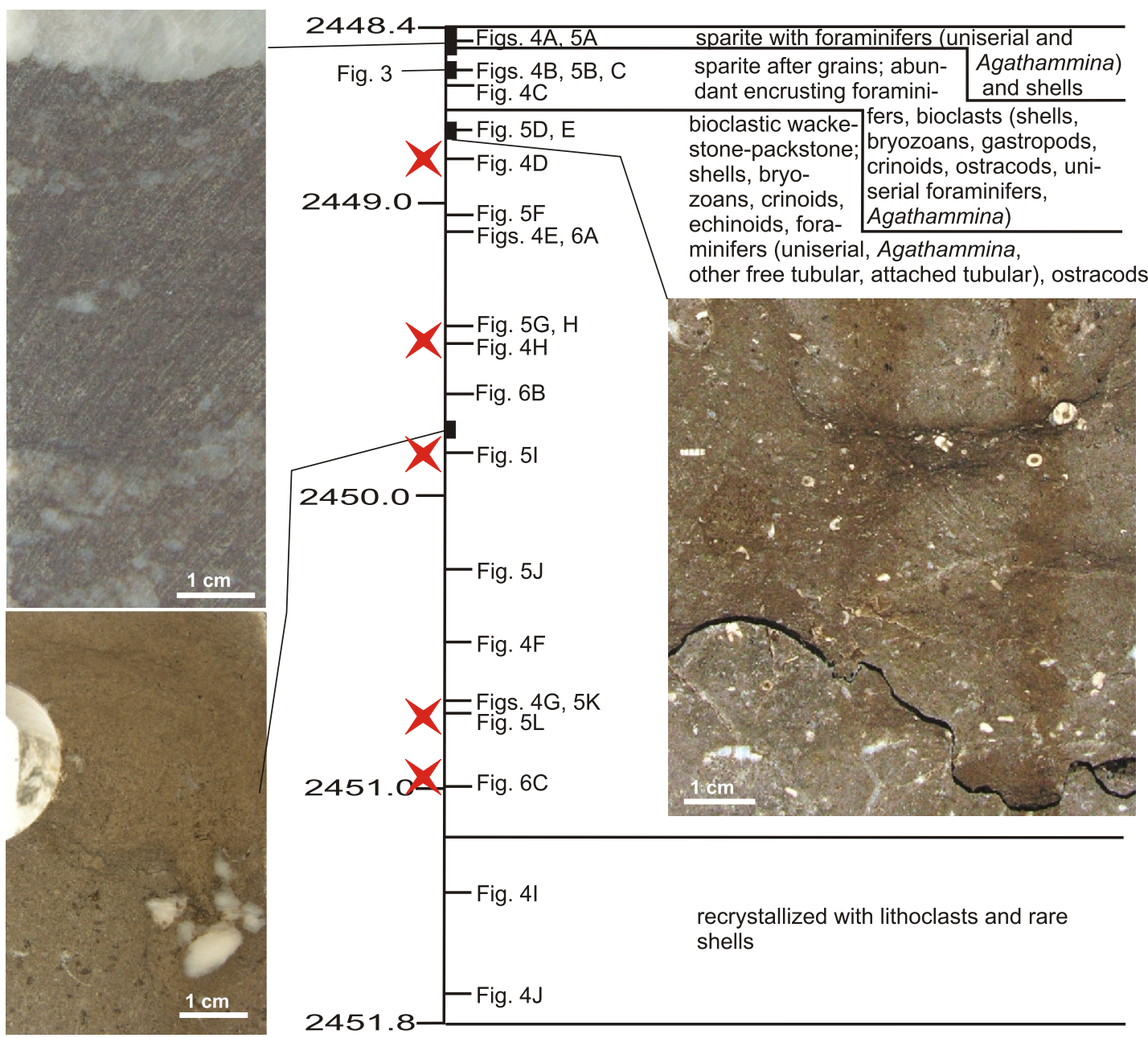

Fig. 2. Characteristics of the Bonikowo 2 sections showing the location of some samples studied (rock samples - this figure and Fig. 3; thin-sections - Fig. 4; fragments of thin-sections - Fig. 5)

Red star shows the common occurrence of uniserial foraminifers and/or Agathammina

(peloidal grainstone according to her interpretation), and calcite (late diagenetic cements), that is a very minor constituent there. Sylwestrzak (2001) concluded that a basal sample (2451.5 m) which shows a uniform dark red colour in CL and non-stoichiometric composition, represents late diagenetic dolomitisation.

Microfacies. The section is micritic except for its topmost part that is sparitic and its lowermost part that is microsparitic (Figs. 2-6).

The lowest interval is composed of recrystallized carbonate, originally probably granular, with lithoclasts (mostly millimetric in size) and rare moulds after shells, either whole ones or their fragments (Figs. 4I, J and 6C). The micritic part is composed of bioclastic (with some peloidal admixture) wackestones and packstones (Figs. 2, 3, 4D-H and 6A, B). The bioclasts are usually $<1 \mathrm{~mm}$ in size and they include fragments of crinoids (Figs. 2, 4E, 5L and 6A), bryozoans (Figs. 5G-I, L and 6A, B), bivalves and brachiopods (Figs. 3, 4D-F and 5G-K), echinoids (Fig. 5G, I), ostracods (Figs. 4D and 6A, B) and foraminifers (Figs. 5G-J, L, 6A, B and 7-9). The pattern of distribution of foraminifers is characterized below. Other fauna does not show clear stratigraphic changes (see Fig. 2).

The upper interval (Figs. 3, 4B, C and 5B-E) is composed of sparitic bodies, usually $>1 \mathrm{~mm}$ in size, that occur in a bioclastic wackestone-packstone matrix containing a slightly poorer fauna

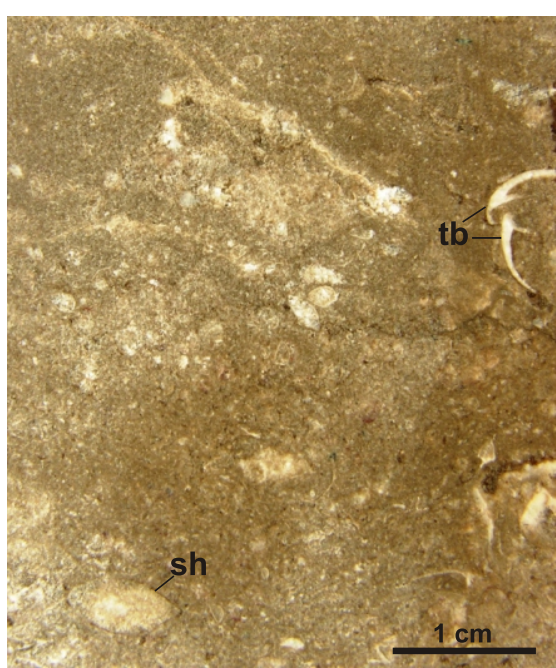

Fig. 3. Patchily recrystallized carbonate with bioclasts

tb - terebratulid brachiopod; sh - shell (bivalve or brachiopod); see also Figures 4B, C and 5B, C 

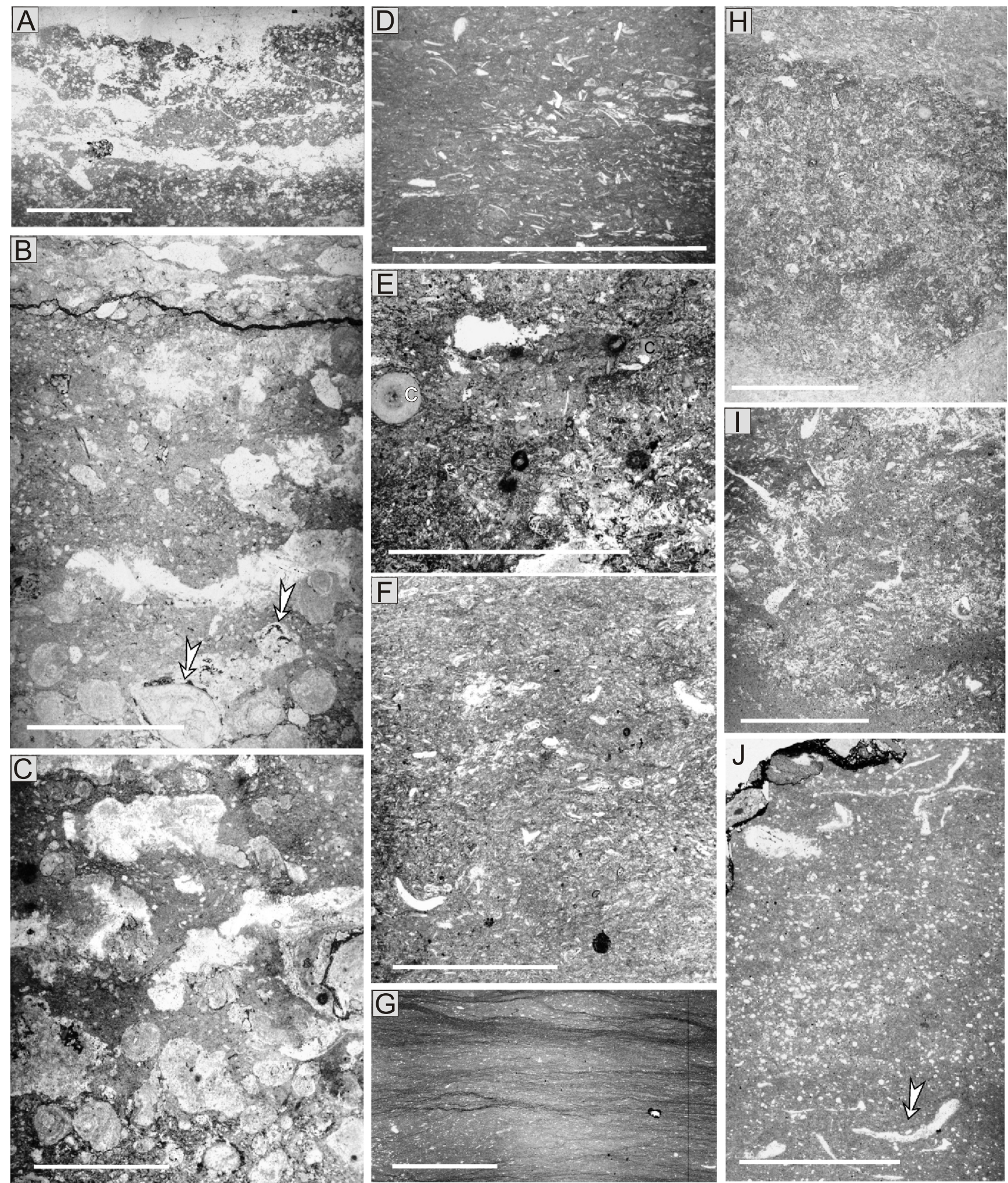

Fig. 4A - recrystallized dolomite from the uppermost part of the Zechstein Limestone showing granular fabric; B, C - recrystallized oncoids (the nuclei some of them consist of bioclasts encrusted by foraminifers - lower part of the photo B) embedded in bioclastic and peloidal matrix with common foraminiferal encrustations (white arrows in B indicate the places shown in Fig. 5B, C); D-F, H - bioclastic wackestone-packstone with peloids [D - mostly shell fragments; E - common crinoids (the largest fragments are marked by "c") and foraminifers; F, H - mostly shell fragments and foraminifers]; G - flaser-laminated wackestone with quartz silt (see Fig. 5K); I, J-microsparite with lithoclasts and recrystallized bioclasts (often moulds after shells; arrow in J indicates dissolved brachiopod shell); thin-section photos of samples the location of which is given in Figure 2; scale bars $=1 \mathrm{~cm}$ 

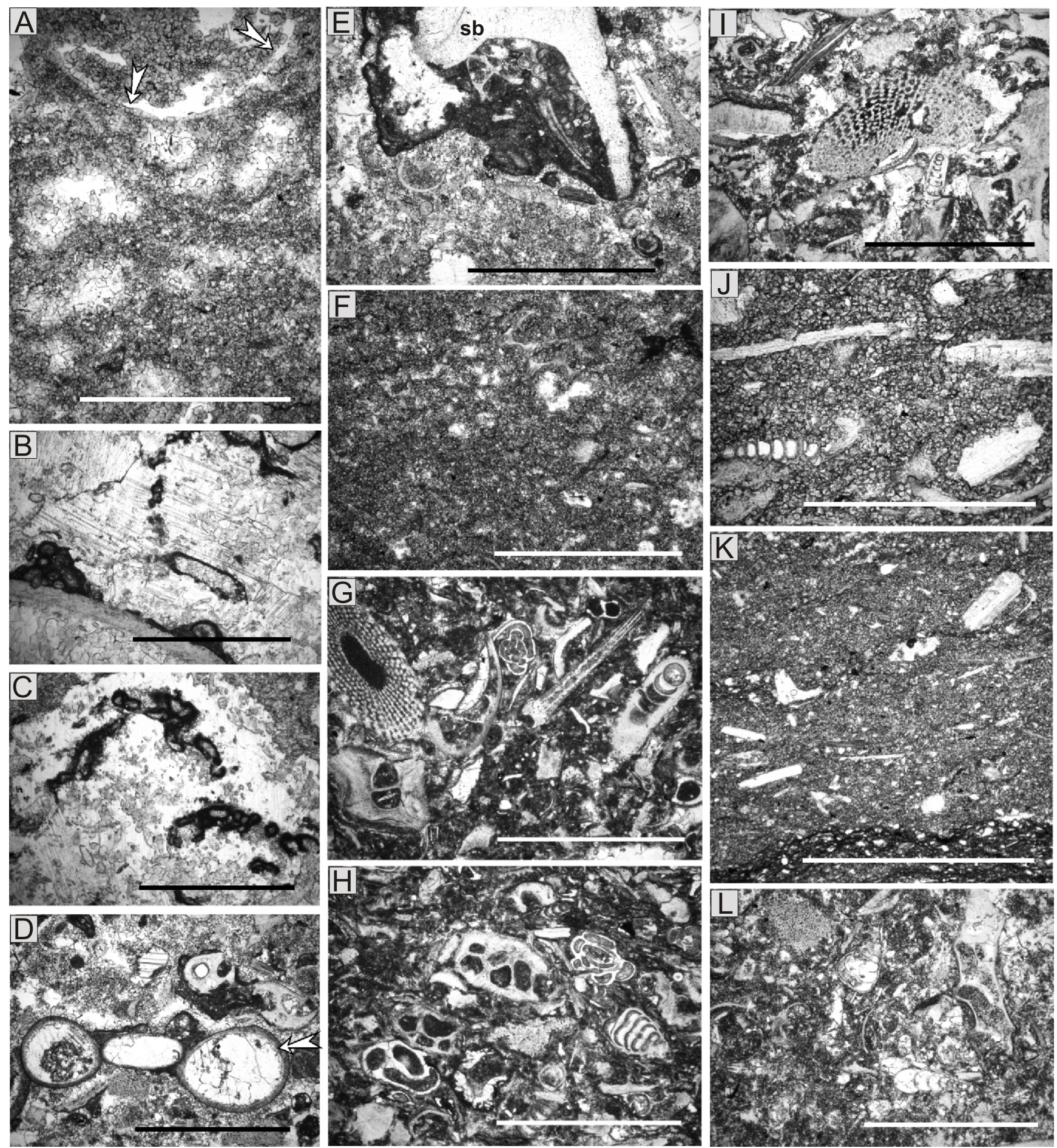

Fig. 5A - sparite showing granular fabric; arrowed are ostracod shells; B, C - foraminifers encrusting shell (B) and previously existing surface, probably microbial (C); D - gastropod (Straparollus or Euomphalus?; arrowed) and bryozoan zoarium fragment (above it) encrusted by foraminifers, E - strophomenid? brachiopod (sb) encrusted by foraminifer-microbial consortium; $F$ microsparite - bioclastic wackestone; G-I - packed bioclastic packstone; some bioclasts are micritized and encrusted by foraminifers; notice echinoid spines (G - upper left corner, I - centre) and bryozoan zoaria (G - lower left corner, H - centre); J recrystallized bioclastic (mostly shell fragments) wackestone; $\mathrm{K}$ - bioclastic wackestone with quartz silt; $\mathrm{L}-$ bioclastic packstone; scale bars $=1 \mathrm{~mm}$

assemblage compared to the preceding interval though, in its lower part, crinoids still occur. Very characteristic of this interval are common encrustations of tubular foraminifers and foraminiferal-microbial consortia developed on bioclasts (Figs. 4B and $5 B, D, E$ ) and other, possibly microbial, substrates that at present are sparitic bodies (Figs. 4B, C and 5A, B).
The topmost part (Figs. 2, 4A and 5A) is recrystallized granular carbonate containing rare shells and foraminifers (uniserial and Agathammina) and common anhydrite nodules. The contact with the Lower Anhydrite is sharp (Fig. 2).

Foraminifers. Foraminifers were recorded in 18 thin-sections; they are lacking in the lowest recrystallized part of the 

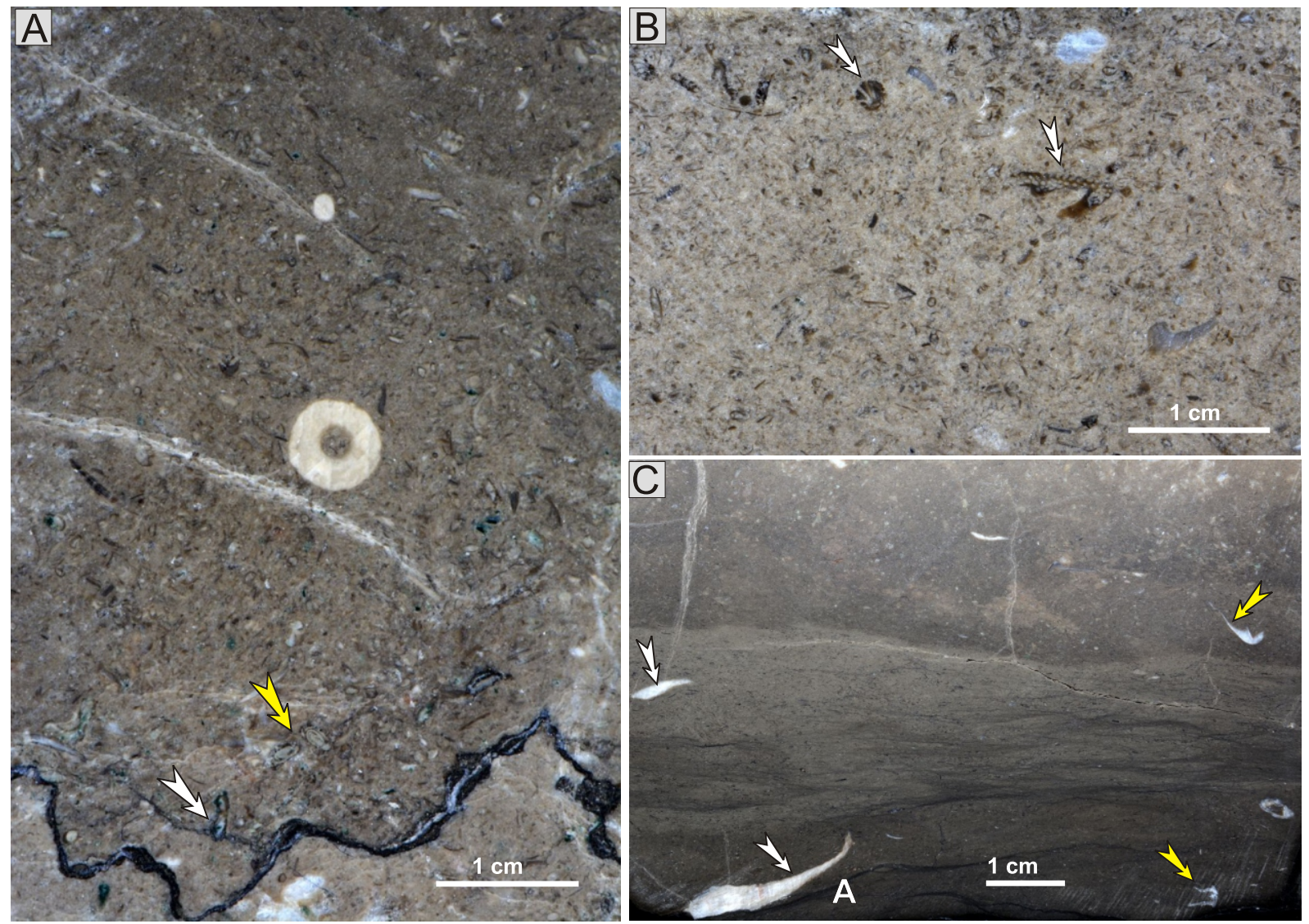

Fig. 6. Photographs of polished slabs

A, B - bioclastic packstone with fragments of branched bryozoans (white arrows), Agathammina (yellow arrow) and crinoids (A, centre); C - laminated wackestone with quartz silt (lower part of the sample) and bioclastic packstone (upper part) with strophomenid (white arrows) and terebratulid (yellow arrows) brachiopods

Zechstein Limestone and they occur in all but one thin-section from the overlying part of the section. Uniserial foraminifers occur in 13 thin sections, Agathammina in 11, encrusting in 7, spiral (other than Agathammina) in 6, and Hemigordius in 2. Agathammina and uniserial and spiral foraminifers occur throughout this overlying part of the section, and encrusting foraminifers occur mainly in its upper part (although they are lacking in the topmost thin section); an exception is the thin-section from the depth $2450.5 \mathrm{~m}$. Foraminifers (except for encrusting ones) are not usually common, but there are instances where uniserial foraminifers and/or Agathammina are quite numerous (e.g., Figs. 4H, 7A-C, J and $9 \mathrm{H}$ ), and these are asterisked in Figure 2.

\section{CARBON AND OXYGEN ISOTOPES}

The results are shown in Figure 10 and are summarized in Table 1

The $\delta^{13} \mathrm{C}$ and $\delta^{18} \mathrm{O}$ curves for calcite and dolomite are similar in shape (Fig. 10A). In the lower part of the section, a negative excursion is observed in the case of both $\delta$ values. The interval with negative $\delta$ values corresponds to the recrystallized level with lithoclasts and the lowest portion of the bioclastic wackestone-packstone succession. Then, $\delta$ values increase to about $+2 \%$ o $\left(\delta^{13} \mathrm{C}\right)$ and about 0 to $-1 \%$ o $\left(\delta^{18} \mathrm{O}\right)$ for the sample shown in Figure 4G. Starting from that sample, $\delta^{13} \mathrm{C}$ curves for calcite and dolomite show a slight upwards-increasing trend, although with some fluctuation, and as a result the topmost sample located close to the Zechstein Limestone-Lower Anhydrite boundary gave the highest $\delta^{13} \mathrm{C}$ values for that section (Table $1)$. In turn, the $\delta^{18} \mathrm{O}$ curve for calcite shows a decrease to ca. $-7 \%$ and then an increase, with some fluctuation, to about $-4 \%$. Most probably, a similar trend is characteristic of the $\delta^{18} \mathrm{O}$ curve for dolomite (the reservation is due to the smaller number of analyses in a critical interval - see Fig. 10A) and for the uppermost part of the section a distinct increase is characteristic, up to the maximum value of $+1.4 \%$ in the topmost sample studied (Fig. 10A).

The data shown in Figure 10B indicate that for the calcite the samples studied do not differ from other samples in the region and for the dolomite the samples from Bonikowo 2 borehole show more negative $\delta^{18} \mathrm{O}$ values.

\section{INTERPRETATION AND DISCUSSION}

The microfacies of most of the Bonikowo 2 section, except for its top part, are characteristic of open marine limestone deposited in deep shelf environments (see Flügel, 1982: table 53). They originated following the rapid inundation of the wide- 

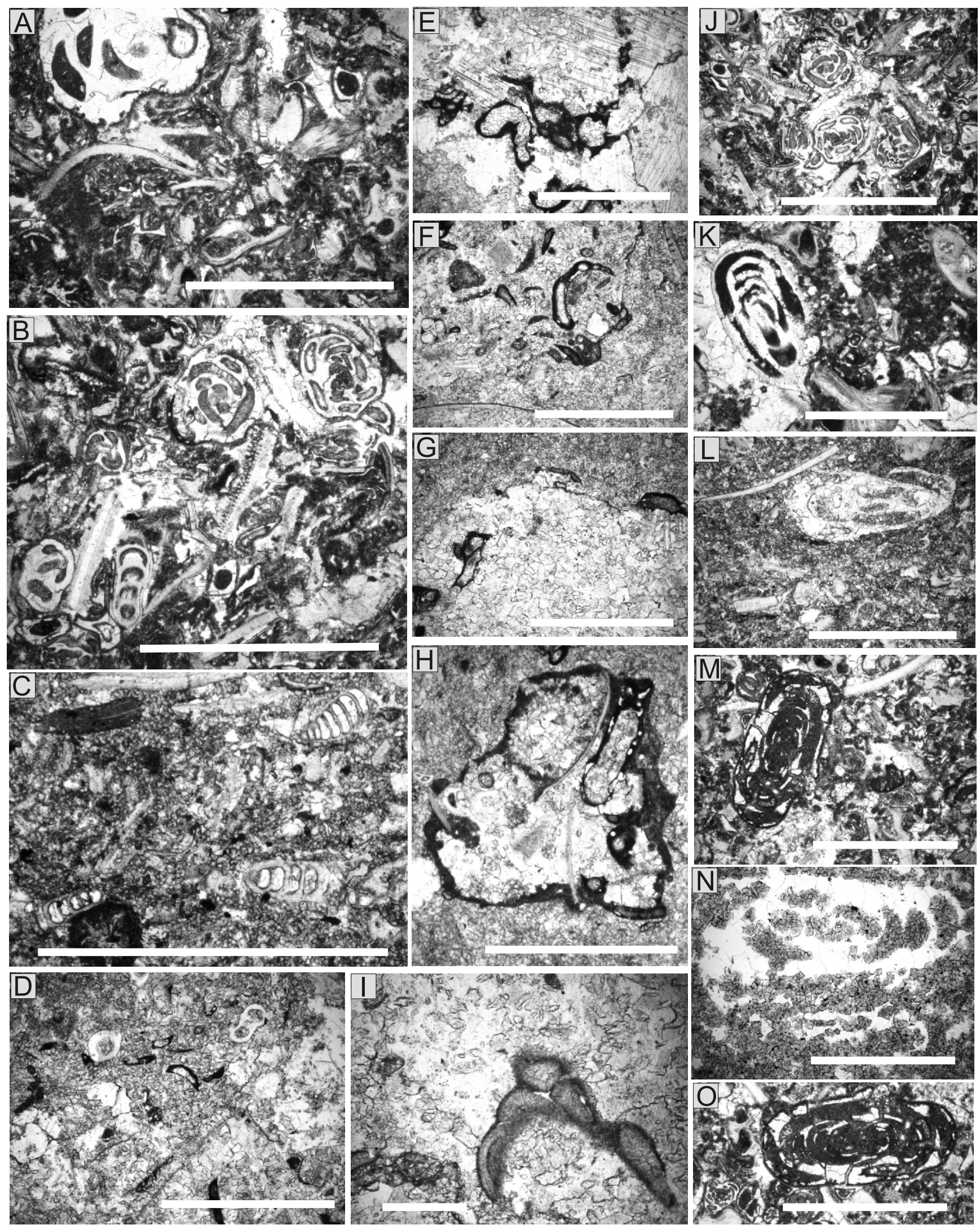

Fig. 7. Foraminifers in thin-sections from the Zechstein Limestone of the Bonikowo 2 borehole

A - Hemigordiopsid; B - Glomospira sp. and Nodosinelloides sp.; C - showing the location of Figure 8C, F; D-I - Palaeonubecularia spp.; J - Pseudoglomospira spp.; K-M, O - Agathammina pusilla; N - Hemigordius? sp.;

scale bar $=1 \mathrm{~mm}$ except for I where scale bar $=200 \mu \mathrm{m}$ 

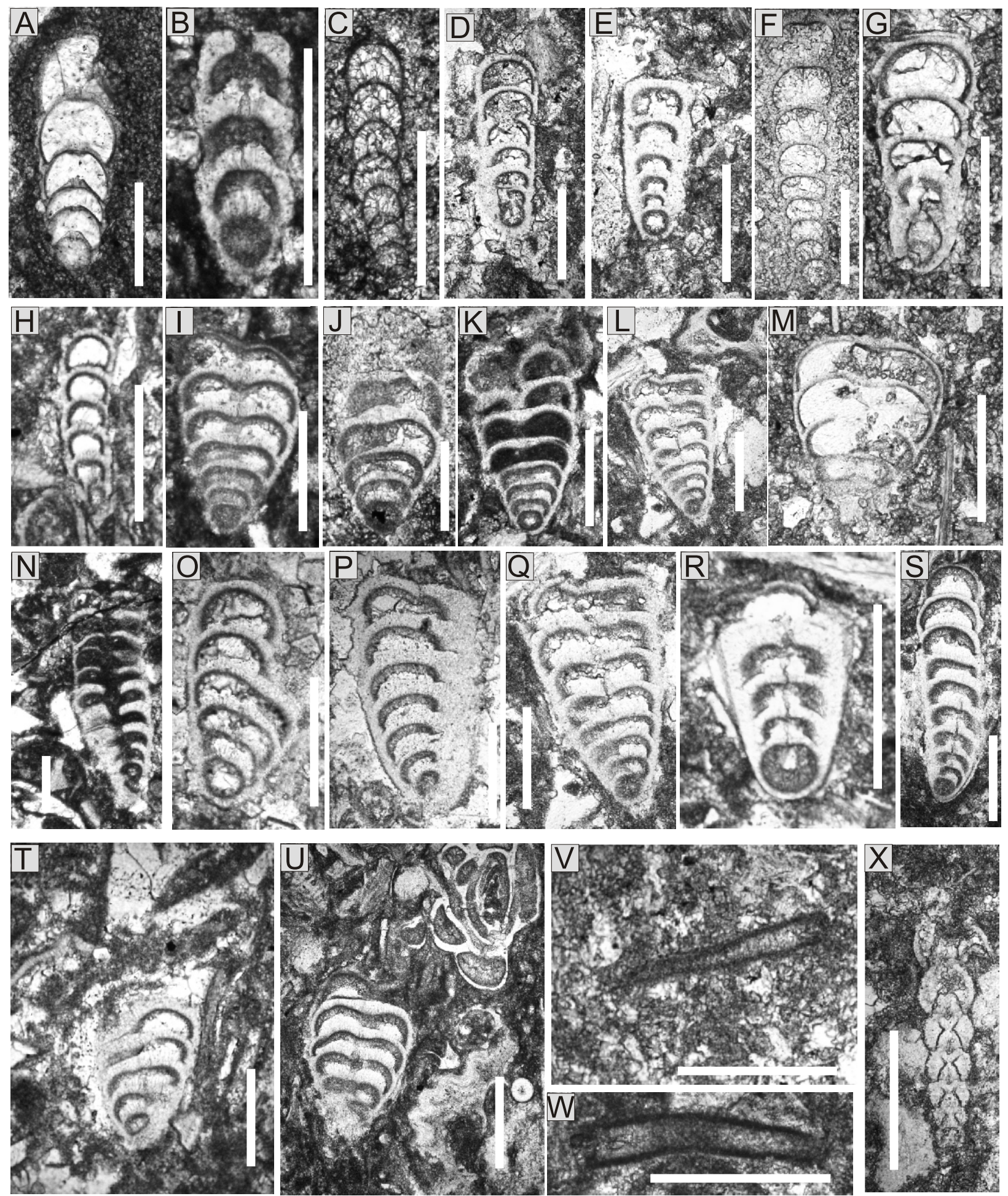

Fig. 8. Foraminifers in thin-sections from the Zechstein Limestone of the Bonikowo 2 borehole

A - Nodosaria permiana; B - Langella? sp.; C - Nodosaria thuringica; D - Pseudonodosaria lata; E, R - Langella sp.; F-H - Nodosinelloides spp.; I, K, L, O, Q, T, U - Geinitzina postcarbonica; J, P - Geinitzina spp.; L, N - Geinitzina richteri;

M - Geinitzina cf. flabellata; S - Geinitzina? sp.; V, W - Earlandia spp.; X - Polarisella woodwardi; scale bar $=200 \mu \mathrm{m}$

spread depression located well below the contemporaneous sea level and thus represent the formation of a marine basin in which the first Zechstein deposits started to accumulate (see D. Peryt et al., 2012).
North of the Wolsztyn palaeo-High, the Zechstein sequence begins with the Kupferschiefer (T1) that is sporadically underlain by the Basal Limestone $(\mathrm{CaO})$, and when those two units are lacking, bioclastic wackestones-packstones of the Zech- 

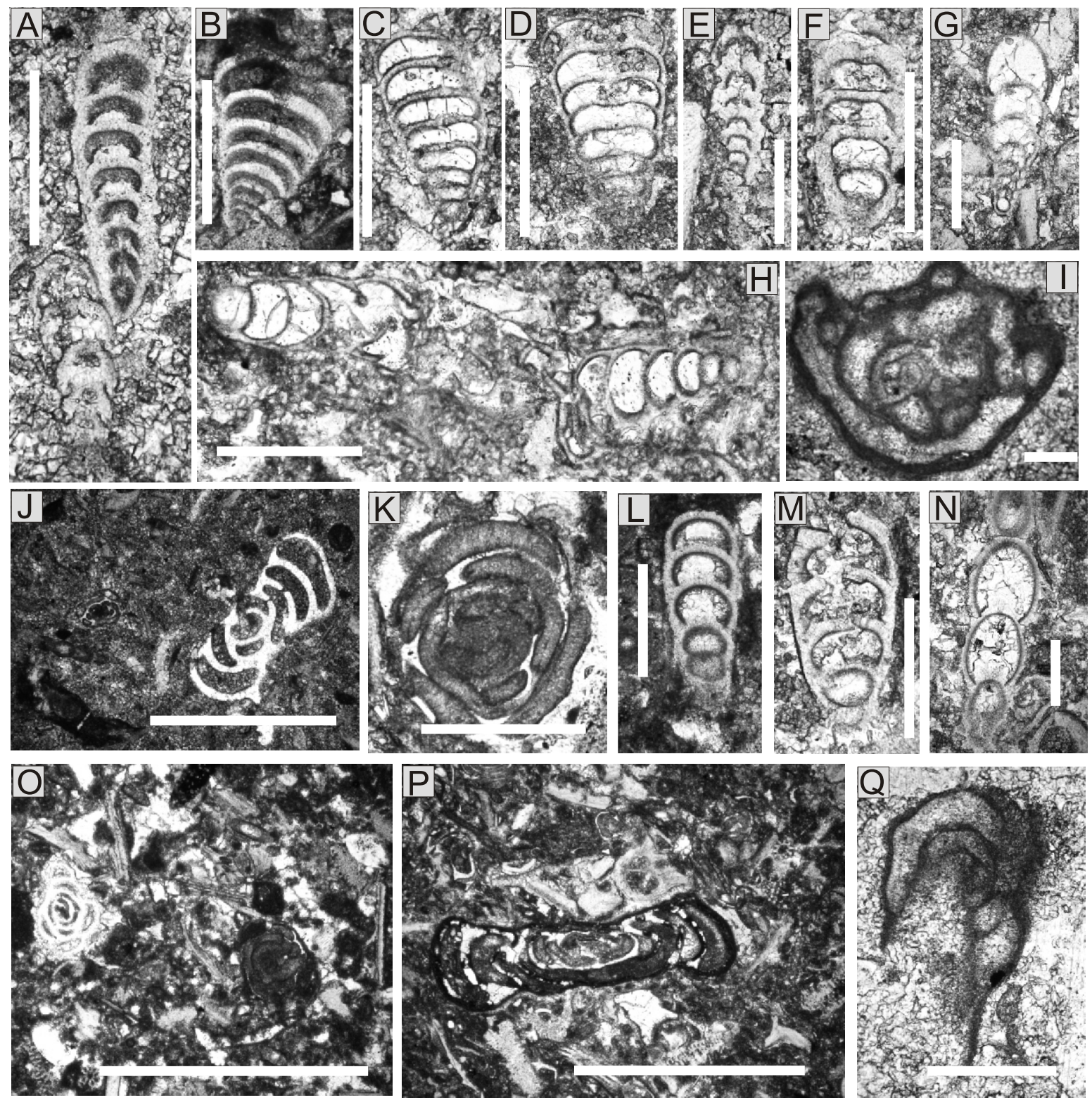

Fig. 9. Foraminifers in thin-sections from the Zechstein Limestone of the Bonikowo 2 borehole

A - Geinitzina? sp. and Polarisella woodwardi; B-D - Geinitzina flabellata; E - Langella sp.; F, M - Langella sp. 2; G Pseudonodosaria lata; $\mathbf{H}$ - uniserial foraminifers; I, Q-Palaeonubecularia spp.; J - Midiella? sp.; $\mathbf{K}$ - Pseudoglomospira sp.; L - Geinitzina? sp.; N - Nodosinelloides sp.; O - hemigordiopsid; P - Hemigordius sp.; scale bar $=200 \mu \mathrm{m}$ except for J, O, P, where scale bar $=1 \mathrm{~mm}$

stein Limestone (Ca1) overlie the Rotliegend siliciclastic deposits (Dyjaczyński and Peryt, 2014). In the Bonikowo 2 borehole, bioclastic wackestones-packstones are underlain by recrystallized carbonate with lithoclasts that otherwise abound in the basal Zechstein deposits developed in the areas where there are reefs but they are often encrusted by tubular foraminifers (D. Peryt et al., 2012), and this is not the case in the Bonikowo 2 borehole. This recrystallized carbonate can be regarded as an aerobic equivalent of the Kupferschiefer, based on the excursion of $\delta^{13} \mathrm{C}$ values towards negative values (cf. Peryt et al., 2012a, 2015).

The depth at which the recrystallized carbonate deposits and bioclastic wackestones-packstones formed did not differ much. Both have suffered intensive bioturbation and hence they are massive in appearance except for two instances in the lower part of bioclastic wackestone-packstone unit where centimetric intercalations of flaser-laminated deposit (such as that shown in Fig. 4G) occur. A similar composition of bioclasts throughout the bioclastic wackestone-packstone unit, and in particular the common occurrence of crinoids in its upper part (e.g., Fig. 2) strongly suggests no essential change in sea water salinity at least up to the deposition of the lower part of the overlying unit (Fig. 4B, C) as the last crinoids were recorded there.

This unit - perhaps most properly described by Smith (1986) as a heterogeneous deposit mainly of ill-sorted oncoids (many of these showing evidence of complex growth histories) 
A

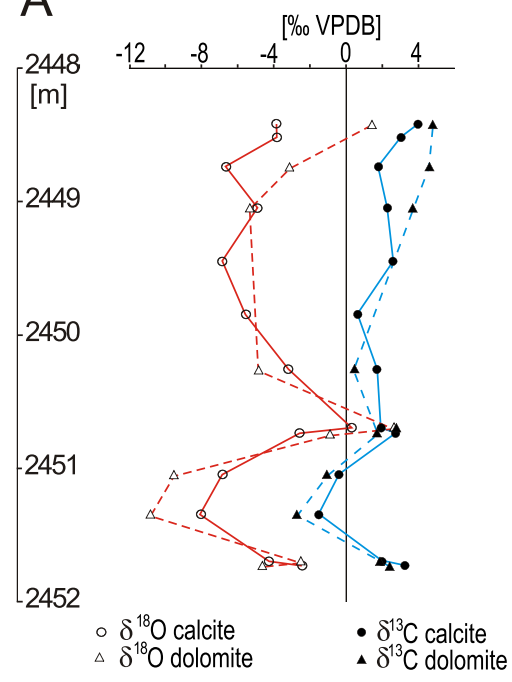

B

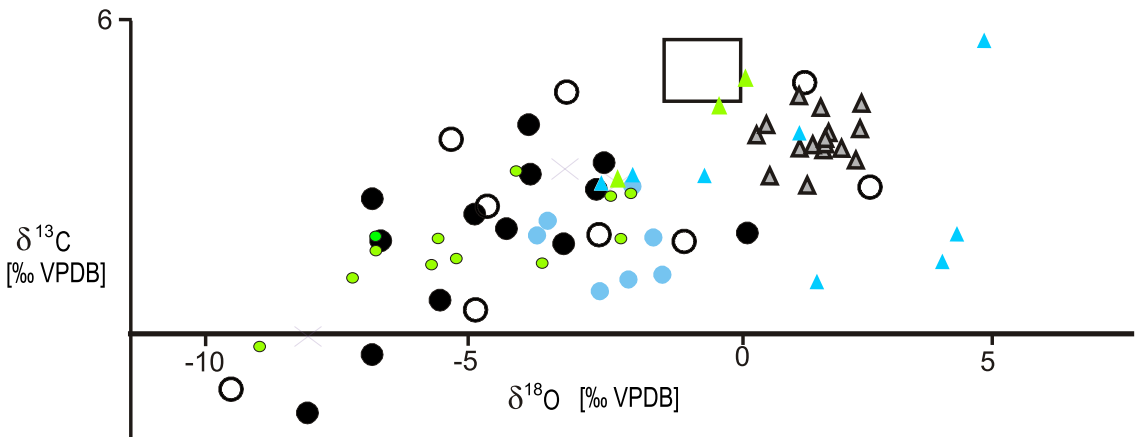

Czarna Wieś 4
$\Delta$ dolomite
calcite
Paproć 28

$\triangle$ dolomite

calcite

Kościan 21

$\Delta$ dolomite

Fig. 10A - carbon and oxygen isotope curves for the Zechstein Limestone of the Bonikowo 2 borehole; B - the plot of $\delta^{13} \mathrm{C}$ and $\delta^{18} \mathrm{O}$ values for the Bonikowo 2 borehole, three other basinal sections in SW Poland (Czarna Wieś 4, Kościan 21 and Paproć 28 boreholes, after Peryt et al., 2015) quadrangle shows the field of plotted data for the Zdrada IG 8 borehole, northern Poland (after Peryt and Peryt, 2012)

Table 1 as very thin basinal sequences of the Zechstein Limestone, such as those described by Peryt et al. (2015), meet all criteria listed by Föllmi (2016) except for authigenesis being practically restricted to the minor precipitation of glaucony and pyrite. An important factor that results in the condensation is the accumulation rate (sedimentary condensation), and the manifestation of reduced sedimentation in the Bonikowo 2 borehole is the common occurrence of bored and encrusted grains in the upper part of the section (Figs. 4B, C and 5B-E).

The $\delta^{13} \mathrm{C}$ values for calcite and dolomite show a slight increase upsection (from about

and peloids with stromatolites - characterizes the basinal sections in the entire Zechstein Basin (e.g., Szaniawski, 1966; Füchtbauer, 1968; Taylor and Colter, 1975; Peryt and Peryt, 1975; Smith, 1986; Becker, 2002; Hammes et al., 2013). The estimates of the depth at which this deposit was formed differ, though most authors advocate deeper water conditions (see discussion in Peryt and Peryt, 2012).

The thin $(8 \mathrm{~cm})$ top unit indicates an overall shallowing and increase in salinity (cf. Peryt and Piątkowski, 1977), and thus except for this unit, no evidence of major difference in depth of depositional environments and in sea water salinity exists throughout the entire Zechstein Limestone sequence of the Bonikowo 2 borehole. The boundary with the Lower Anhydrite is sharp as in other condensed sequences in the region (e.g., Dyjaczyński and Peryt, 2014: fig. 4A).

The Bonikowo 2 section is thicker $(3.4 \mathrm{~m})$ than the much thinner condensed sequence in western Poland (Dyjaczyński and Peryt, 2014; Peryt et al., 2015) but this is the only characteristic that differentiates the Bonikowo 2 section from the other sequences. As recently commented by Föllmi (2016), the term "condensation" (and "condensed sediment") are applied in various ways, and proposed a set of sedimentological, mineralogical and palaeontological criteria to define the "condensed" beds. Both the Bonikowo 2 borehole section as well $+3.2 \%$ at the base of the unit to ca. $+4 \%$ at its top - Fig. 10A). In the case of dolomite the increase is more distinct (from about $+2.4 \%$ at the base of the unit to ca. $+4.8 \%$ o at its top - Fig. 10A). A similar upsection increase is characteristic of basinal sections both in western Poland (Peryt et al., 2015) and in northern Poland (Peryt and Peryt, 2012) and was interpreted as due to a global increase during the time span of ca. 1 My when the Zechstein Limestone was deposited. In the recrystallized carbonate with lithoclasts a distinct decrease in both $\delta^{13} \mathrm{C}$ values is related to diagenesis that in general leads to decrease of both values (Hudson, 1977).

If the highest $\delta^{18} \mathrm{O}$ value of calcite is regarded as reflecting the temperature of the ambient fluid, then the calculated palaeotemperature using the equation of Epstein et al. (1953) would yield values of ca. $14^{\circ} \mathrm{C}$ for calcite if the $\delta^{18} \mathrm{O}$ of water $=$ $0 \%$ is assumed, $18.3^{\circ} \mathrm{C}$ when the $\delta^{18} \mathrm{O}$ of water $=+1 \%$, and $22.9^{\circ} \mathrm{C}$ when the $\delta^{18} \mathrm{O}$ of water $=+2 \%$ (cf. Fig. 10). The Zechstein Limestone sea was surrounded by a widespread continental area and because of the arid subtropical conditions (cf. Fluteau et al., 2001; Peryt et al., 2012b), the first value is clearly far below the range estimated for contemporaneous sea water and thus the assumed sea water $\delta^{18} \mathrm{O}$ would have to be enriched in ${ }^{18} \mathrm{O}$ by about $+2 \%$. 
The $\delta^{18} \mathrm{O}$ value of calcite is $2.6 \%$ lower than those of coexisting dolomite, if both minerals precipitate in isotopic equilibrium at the same temperature from the same solution (Vasconcelos et al., 2005). The difference between average $\delta^{18} \mathrm{O}$ values for calcite and dolomite is small (ca. $0.4 \%$; Table 1 ), and the difference between maximum $\delta^{18} \mathrm{O}$ values for calcite and dolomite $(2.3 \%)$ is close to the theoretical equilibrium value, yet the observed differences imply that calcite and dolomite precipitated either at different temperatures and/or from different solutions. The same conclusion was previously reached for the Paproć 28 and Czarna Wieś 4 boreholes which show a difference slightly above 4\% (Peryt et al., 2015: fig. 10).

A

Dolomite

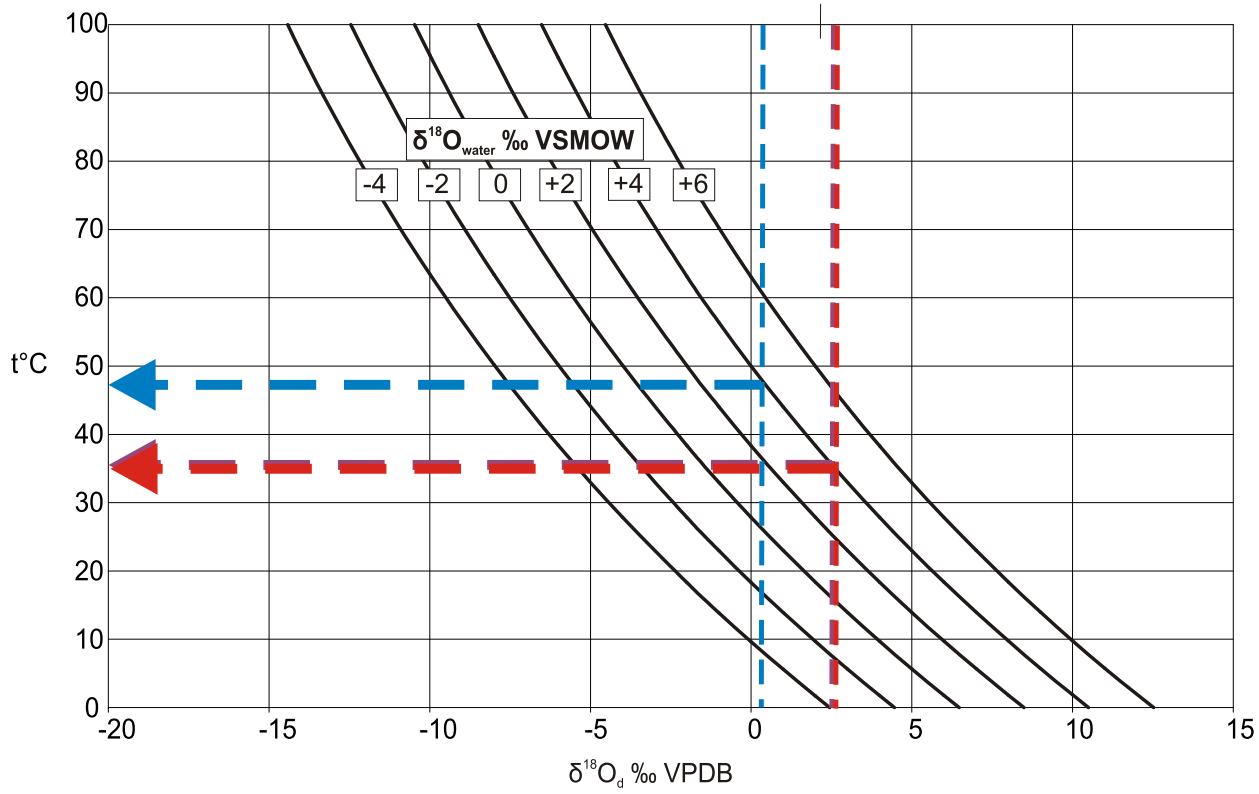

B

Calcite

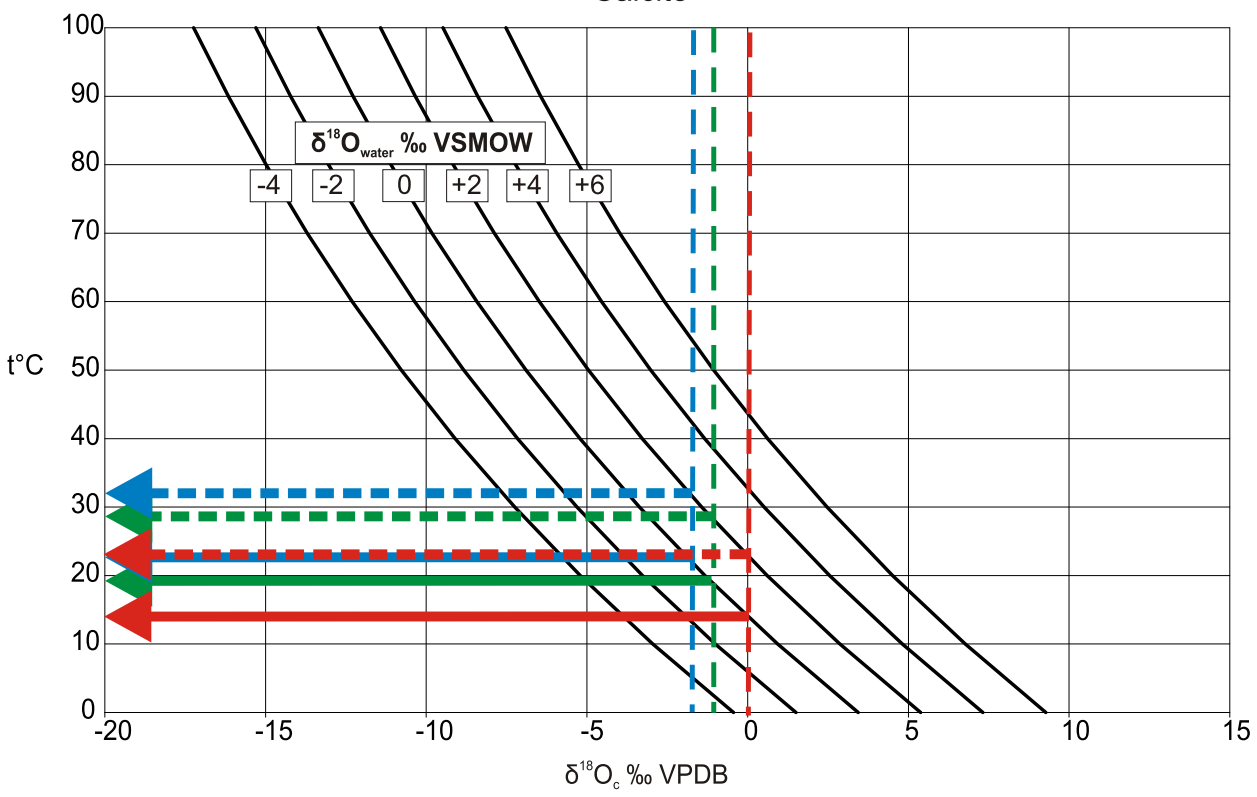

Fig. 11. Relationship between precipitation temperature and oxygen isotopic composition of water for dolomites (A) and calcites (C), and its interpretation for average values for the Bonikowo 2 borehole (red) as well as, for comparison, three other boreholes (after Peryt et al., 2015) from the basinal sections: Kościan 21 (purple), Paproć 28 (green) and Czarna Wieś 4 (blue)

Coloured (red, purple, green or blue) vertical lines refer to maximum $\delta^{18} \mathrm{O}$ values in dolomite and calcite (solid line for average value, and dashed line for maximum value), arrows point to possible precipitation temperatures for assumed oxygen isotopic composition of water (in A, dashed arrows indicate calculated temperature for maximum $\delta^{18} \mathrm{O}$ value assuming oxygen isotopic composition of water of $+4 \%$ SMOW; in B, solid arrows indicate oxygen isotopic composition of water of $0 \%$ SMOW and dashed arrows of $+2 \%$ SMOW) 
The maximum $\delta^{18} \mathrm{O}$ value $(+2.66 \%$ ) for dolomite reflects the temperature of the dolomitising fluid equal to $35^{\circ} \mathrm{C}$ if a $\delta^{18} \mathrm{O}$ of water $=+4 \%$ is assumed. The temperature would increase if the $\delta^{18} \mathrm{O}$ of water is higher: for example, $46^{\circ} \mathrm{C}$ when $\delta^{18} \mathrm{O}$ of water $=+6 \%$ o (Fig. 11). These values can be expected if the early reflux model of dolomitisation is applied.

A comparison of the Bonikowo 2 and Kościan 21 boreholes shows that, in both, the dolomite shows similar maximum $\delta^{13} \mathrm{C}$ values $(+4.78 \%$ in Bonikowo 2 and $+4.57 \%$ in Kościan 21$)$ and $\delta^{18} \mathrm{O}$ values ( $+2.66 \%$ in Bonikowo 2 and $+2.5 \%$ in Kościan 21$)$, but the minimum (and as the result, the mean) values are distinctly lower in Bonikowo 2 . This is due to the depleted intervals that occur below and above the maximum $\delta^{18} \mathrm{O}$ values, these isotopic signatures reflecting late diagenesis (cf. Sylwestrzak, 2001). They can reflect either a high-temperature event, which is the preferred interpretation, or meteoric water influence, or both. Sylwestrzak (2000) considered that in general dolomites related to the Wolsztyn reefs originated through mixing as indicated by negative $\delta^{18} \mathrm{O}$ values and a partial, matrix-selective dolomitisation, but subsequently Jasionowski et al. (2014) concluded, based on low oxygen isotopic ratios $\left(\delta^{18} \mathrm{O}\right.$ as low as $-9 \%$ VPDB) and the presence of saddle dolomite, that many of the dolomites gained their present isotopic composition when buried in relatively high-temperature conditions. On the other hand, no isotopic support for a water-mixing mechanism is yet documented (Jasionowski et al., 2014).

\section{IMPLICATIONS}

When compared to the sequences characterized by Peryt et al. (2015), the Bonikowo 2 section shows a greater thickness, and at the same time more common bioclastic packstones. The section is located in close proximity to a reef like that of the Kościan 21 borehole but the basinward location of the Bonikowo 2 reef was the factor promoting the flourishing of fauna due to increased supply of nutrients.

The diversity and abundance of foraminifers is moderately high in the Bonikowo 2 borehole except for the lowermost part of the section that is recrystallized carbonate with lithoclasts regarded as an aerobic equivalent of the Kupferschiefer. Peryt and Peryt (2012 with references therein) concluded that the predominance of lagenides throughout the Zechstein Limestone basin section studied by them (Zdrada IG 8) suggests dysaerobic conditions. Earlier study of typical condensed sequences (Peryt et al., 2015) suggested continual dysaerobic conditions, and possibly an elevated salinity of sea water, during deposition of thin basinal Zechstein Limestone deposits. Our temperature interpretation of the highest $\delta^{18} \mathrm{O}$ value of calcite recorded in the Bonikowo 2 section leads to the conclusion that the assumed sea water $\delta^{18} \mathrm{O}$ would have to be enriched in ${ }^{18} \mathrm{O}$ by about $+2 \%$.

The sharp boundary with the overlying Lower Anhydrite is due to the most common feature of evaporites: they start to precipitate immediately when the brines reach saturation (e.g., Caruso et al., 2016). The essential increase in sea water salinity thus had to occur during the deposition of the highest $(8 \mathrm{~cm}$ thick) unit (recrystallized granular carbonate) and eventually during the upper part of the heterogeneous deposit mainly of ill-sorted oncoids and peloids with stromatolites, above the last occurrence of echinoids.

The case of the Bonikowo 2 sections generally supports the previous suggestion that the thin condensed sequences probably record the entire interval of the Zechstein prior to the onset of evaporite deposition (Peryt et al., 2015). The lower part of the Bonikowo 2 section is recrystallized, however, and this interval, critical for stratigraphic correlation based on carbon isotope stratigraphy, shows a depletion in both $\delta$ values. Ignoring this deviation, $\delta^{13} \mathrm{C}$ values show a slight upwards decrease that was previously recorded in other basinal sections in Poland (Peryt and Peryt, 2012; Peryt et al., 2015).

\section{CONCLUSIONS}

The Zechstein Limestone of the Bonikowo 2 borehole section is thicker $(3.4 \mathrm{~m})$ than other condensed sequences in the area adjacent to the Wolsztyn reefs but its microfacies development is similar. Most of the section is composed of bioclastic wackestones-packstones containing common crinoids which strongly suggest no essential change in sea water salinity at least to the deposition of the lower part of the overlying unit (a heterogeneous deposit mainly of ill-sorted oncoids and peloids with stromatolites) as the last crinoids were recorded there. The thin $(8 \mathrm{~cm})$ top unit indicates an overall shallowing and increase in salinity leading to the onset of evaporite deposition.

The highest $\delta^{18} \mathrm{O}$ value of calcite recorded in the Bonikowo 2 borehole $\left(+0.32 \%\right.$ ) indicates a temperature of $22.9^{\circ} \mathrm{C}$ when the $\delta^{18} \mathrm{O}$ of water $=+2 \%$ is assumed.

Foraminiferal assemblages are dominated by lagenids suggesting dysaerobic conditions throughout most deposition, except for the lowermost, recrystallized part of the section.

Acknowledgements. The study was financed by the National Science Centre (decision No. DEC-2013/11/B/ST10/04949). We are grateful to the Polish Oil and Gas Company for the access to core and thin sections, to K. Chłódek for logistical support, and to B. Błażejowski, J. Zalasiewicz and an anonymous reviewer for helpful remarks.

\section{REFERENCES}

Al-Aasm, I.S., Taylor, B.E., South, B., 1990. Stable isotope analysis of multiple carbonate samples using selective acid extraction. Chemical Geology, 80: 119-125.

Becker, F., 2002. Zechsteinkalk und Unterer Werra-Anhydrit (Zechstein 1) in Hessen: Fazies, Sequenzstratigraphie und Diagenese. Geologische Abhandlungen Hessen, 109: 1-231.

Caruso, A., Pierre, C., Blanc-Valleron, M.M., Rouchy, J.-P., 2016. Reply to the comment on "Carbonate deposition and diagenesis in evaporitic environments: the evaporative and sulphur-bearing limestones during the settlement of the Messinian Salinity Crisis in Sicily and Calabria" by Caruso et al., 2015. Palaeogeography, Palaeoclimatology, Palaeoecology, 429: 136-162.

Denison, R.E., Peryt, T.M., 2009. Strontium isotopes in the Zechstein (Upper Permian) anhydrites of Poland: evidence of varied meteoric contributions to marine brines. Geological Quarterly, 53 (2): 159-166. 
Dyjaczyński, K., Kucharczyk, K., 2000. Rafa wapienia cechsztyńskiego Bonikowo w świetle sejsmiki 3D i analizy paleogeologicznej (in Polish). Przegląd Geologiczny, 48: 466

Dyjaczyński, K., Peryt, T.M., 2014. Controls on basal Zechstein (Wuchiapingian) evaporite deposition in SW Poland. Geological Quarterly, 58 (3): 475-492.

Dyjaczynski, K., Górski, M., Mamczur, S., Peryt, T.M., 2001. Reefs in the basinal facies of the Zechstein Limestone (Upper Permian) of Western Poland. Journal of Petroleum Geology, 24 265-285.

Epstein, S. Jr., Buchsbaum, R., Lowenstam, H.A., Urey, H.C., 1953. Revised carbonate-water isotopic temperature scale. GSA Bulletin, 64: 1315-1326.

Flügel, E., 1982. Microfacies Analysis of Limestones. Springer, Berlin, Heidelberg.

Fluteau, F., Besse, J., Ramstein, G., 2001. The Late Permian climate. What can be inferred from climate modelling concerning Pangea scenarios and Hercynian range altitude? Palaeogeography, Palaeoclimatology, Palaeoecology, 167: 39-71.

Föllmi, K.B., 2016. Sedimentary condensation. Earth-Science Reviews, 152: 143-180.

Füchtbauer, H., 1968. Carbonate sedimentation and subsidence in the Zechstein Basin (Northern Germany). In: Recent Developments in Carbonate Sedimentology in Central Europe (eds. G. Müller and G.M. Friedman): 196-204. Springer, Heidelberg

Hammes, U., Krause, M., Mutti, M., 2013. Unconventional reservoir potential of the upper Permian Zechstein Group: a slope to basin sequence stratigraphic and sedimentological evaluation of carbonates and organic-rich mudrocks, Northern Germany. Environmental Earth Sciences, 70: 3797-3816.

Hara, U., Słowakiewicz, M., Raczyński, P., 2013. Bryozoans (trepostomes and fenestellids) in the Zechstein Limestone (Wuchiapingian) of the North Sudetic Basin (SW Poland): palaeoecological implications. Geological Quarterly, 57 (3): 417-432.

Hudson, J.D., 1977. Stable isotopes and limestone lithification. Journal of the Geological Society, 133: 637-660.

Jasionowski, M., Peryt, T.M., Durakiewicz, T., 2014. Polyphase dolomitisation of the Wuchiapingian Zechstein Limestone (Ca1) isolated reefs (Wolsztyn Palaeo-Ridge, Fore-Sudetic Monocline, SW Poland). Geological Quarterly, 58 (3): 493-510.

Kiersnowski, H., Peryt, T.M., Buniak, A., Mikołajewski, Z., 2010. From the intra-desert ridges to the marine carbonate island chain: middle to late Permian (Upper Rotliegend-Lower Zechstein) of the Wolsztyn-Pogorzela high, west Poland. Geological Journal, 44: 319-335.

Kotarba, M.J., Peryt, T.M., Kosakowski, P., Więcław, D., 2006. Organic geochemistry, depositional history and hydrocarbon generation modelling of the Upper Permian Kupferschiefer and Zechstein Limestone strata in south-west Poland. Marine and Petroleum Geology, 23: 371-386.

Peryt, D., Peryt, T.M., Raczyński, P., Chłódek, K., 2012. Foraminiferal colonization related to the Zechstein (Lopingian) transgression in the western part of the Wolsztyn Palaeo-Ridge area, Western Poland. Geological Quarterly, 56 (3): 529-546.

Peryt, T.M., 1994. The anatomy of a sulphate platform and adjacent basin system in the Łeba sub-basin of the Lower Werra Anhydrite (Zechstein, Upper Permian), northern Poland. Sedimentology, 41: 83-113.

Peryt, T.M., Peryt, D., 1975. Association of sessile tubular foraminifera and schizophytic algae. Geological Magazine, 112 612-614.

Peryt, T.M., Peryt, D., 1977. Zechstein foraminifera from the Fore-Sudetic monocline area (West Poland) and their paleoecology (in Polish with English summary). Rocznik Polskiego Towarzystwa Geologicznego, 47: 301-326.

Peryt, T.M., Peryt, D., 2012. Foraminiferal and geochemical records of environmental changes during Zechstein Limestone (Lopingian) deposition in Northern Poland. Geological Quarterly, 56 (1): 187-198.

Peryt, T.M., Piątkowski, T.S., 1977. Stromatolites from the Zechstein Limestone (Upper Permian) of Poland. In: Fossil Algae (ed. E. Flügel): 124-135. Springer.

Peryt, T.M., Ważny, H., 1980. Microfacies and geochemical development of the basin facies of the Zechstein Limestone (Ca1) in western Poland. Contributions to Sedimentology, 9: 279-306.

Peryt, T.M., Piątkowski, T.S., Wagner, R., 1978. Lithology and paleogeography of the Zechstein carbonate horizons. In: Lithofacies-Paleogeographical Atlas of the Permian of Platform Areas of Poland, Textual Part (ed. S. Depowski): 21-23. Instytut Geologiczny, Warszawa.

Peryt, T.M., Geluk, M.C., Mathiesen, A., Paul, J., Smith, K., 2010a. Zechstein. In: Petroleum Geological Atlas of the Southern Permian Basin Area (eds. J.C. Doornenbal and A.G. Stevenson): 123-147. EAGE Publications b.v., Houten.

Peryt, T.M., Hałas, S., Hryniv, S.P., 2010b. Sulphur and oxygen isotope signatures of late Permian Zechstein anhydrites, West Poland: seawater evolution and diagenetic constraints. Geological Quarterly, 54 (4): 387-400.

Peryt, T.M., Durakiewicz, T., Kotarba, M.J., Oszczepalski, S., Peryt, D., 2012a. Carbon isotope stratigraphy of the basal Zechstein (Lopingian) strata in Northern Poland. Geological Quarterly, 56 (2): 285-298.

Peryt, T.M., Raczyński, P., Peryt, D., Chłódek, K., 2012b. Upper Permian reef complex in the basinal facies of the Zechstein Limestone (Ca1), western Poland. Geological Journal, 46: 537-552.

Peryt, T.M., Hałas, S., Peryt, D., 2015. Carbon and oxygen isotopic composition and foraminifera of condensed basal Zechstein (Upper Permian) strata in western Poland: environmental and stratigraphic implications. Geological Journal, 50: 446-464.

Rosenbaum, J., Sheppard, S.M., 1986. An isotopic study of siderites, dolomites and ankerites at high temperatures. Geochimica et Cosmochimica Acta, 50: 1147-1150.

Smith, D.B., 1986. The Trow Point Bed - a deposit of Upper Permian marine oncoids, peloids and columnar stromatolites in the Zechstein of NE England. Geological Society Special Publications, 22: 113-125.

Sylwestrzak, J., 2000. Zróżnicowanie raf mszywiołowych Ca1 w świetle wyników badań petrograficznych i izotopowych (streszczenie posteru) (in Polish). Przegląd Geologiczny, 48: 465

Sylwestrzak, J., 2001. Badania petrologiczne rafy wapienia cechsztyńskiego w rejonie Bonikowa (in Polish). NGA, No. Inw. 685/2002, PIG-PIB, Warszawa.

Szaniawski, H., 1966. Facial development and palaeogeography of the Zechstein within the elevation of Łeba (in Polish with English summary). Acta Geologica Polonica, 16: 229-247.

Taylor, J.C.M., Colter, V.S., 1975. Zechstein of the English sector of the Southern North Sea Basin. In: Petroleum and the Continental Shelf of North-West Europe (ed. A.W. Woodland), 1: 249-263. Applied Science Publishers, Barking.

Vasconcelos, C., McKenzie, J.A., Warthmann, R., Bernasconi, S.M., 2005. Calibration of the $\delta^{18} \mathrm{O}$ paleothermometer for dolomite precipitated in microbial cultures and natural environments. Geology, 33: 317-320.

Ziemianin, K., 2012. Correlations of petrophysical parameters with facies analysis of cores from the Bonikowo-1, Bonikowo-2 and Kokorzyn-2 wells (in Polish). Nafta-Gaz, 68: 153-164. 